\title{
A Model of Supplier Selection Under Vendor Managed Inventory Contract
}

\author{
Zabrina Masud Mangka, Suparno, and Erwin Widodo \\ Department of Industrial and Systems Engineering, Institut Teknologi Sepuluh Nopember, Surabaya \\ e-mail: suparno@ie.its.ac.id
}

\begin{abstract}
VMI is the main concept for gaining accurate information and information sharing from customers to suppliers to achieve low safety stock levels, efficient inventory cost, and a reduction of ordering cost. There are many suppliers who supply spare part products under the VMI contract. Therefore, the company needs to make a decision for selecting a qualified supplier in order to improve customer service level and customer satisfaction. In addition, the uncertainty and vagueness of the expert's opinion is the prominent characteristic of the problem. Therefore an extensively used multi-criteria decision-making tool AHP can be utilized as an approach for supplier selection problems. This paper reveals the application of AHP model determining the best supplier with respect to selected criteria for selecting the best supplier under the VMI contract among the alternatives. There are criteria in this study namely quality, price, delivery, service, supplier's background, and Information technology which include thirty subcriteria covers in the VMI contract. This research might be identified the critical criteria for supplier selection under the VMI contract.
\end{abstract}

Keywords-AHP, Multi Criteria Decision Making, Spare Parts, Supply Chain, VMI.

\section{INTRODUCTION}

$\mathrm{S}_{\mathrm{n}}^{\mathrm{u}}$ UPPLIER selection, which includes multi criteria and multiple conflicting objectives, can be defined as the process of finding the right suppliers with the right quality at the right price, at the right time, and in the right quantities. It is noted that, manufacturers spend more than $60 \%$ of its total sales on purchased items [1]. Therefore, selecting the right supplier significantly reduces purchasing costs, improves competitiveness in the market, and enhances end-user satisfaction [2]. Since this selection process mainly involves the evaluation of different criteria and various supplier attributes, it can be considered as a multiple criteria decision making (MCDM) problem [3]. Based on several criteria and alternatives to be considered, various decision-making methods have been proposed to provide a solution to this problem [4].

As a pioneer in the supplier selection problem, Dickson [5] identified 23 different criteria for selecting suppliers, including quality, delivery, performance history, warranties, price, technical capability, and financial position [6]. With a thorough literature survey, Weber, et al. [7] reviewed 74 different articles by classifying into three categories; linear weighting methods, mathematical programming models, and statistical approaches. Following Weber et al. [7], De Boer et al. [8], identified four stages for supplier selection including; definition of the problem, formulation of criteria, qualification, and final selection respectively [9].
The mining industry has special factors with the association in a large amount of maintenance. The mining company has first to deal with high safety stock levels, inefficient inventory cost, and an increase in ordering cost as well as issues on service level. It caused by suppliers provide higher costs but lower quality of spare parts. The implementation of VMI can provide potential benefits to both the vendor and the customer when they properly applied [10].

The aim of this study is to set a model of supplier selection under the VMI contract in order to identify the criteria for preventing bullwhip effect, reduce the total cost of service inventory stocks and ordering. The purpose of improving good communication and more accurate information data sharing, and quality of services for end-user satisfaction in the mining sector. Therefore, the analytical model for making a decision is the Analytical Hierarchy Process (AHP), which it can be able to evaluate the weight of each criterion in order to evaluate the suppliers for a mining company to adopt VMI.

\section{PROBLEM IDENTIFICATION}

The selection of suppliers is crucial to the success of a mining company because the cost and quality of products and services have an important role in the production chain process. Previously, supplier were chosen based on the price offered at the tender. The supplier selection process is a problem solving process, which includes defining the problem, formulating criteria and sub-criteria, qualifying, and selecting suppliers [11].

VMI is a relationship between organizations where retailers share end product demand information and inventory level information with suppliers and suppliers use this information for better retailer inventory management. "Although it depends on the form of the agreement, the benefits of VMI generally include an increase in service levels and a reduction in supply chain costs, reduced uncertainty in customer demand, reduced outgoing stock and exit frequency, and reduced bullwhip effect." [10].

PT XYZ as a mining company faces problems related to supplier performance that is not yet stable. The 67 suppliers hold FPA (Forward Purchase Agreement) or VHS (Vendor Held Stock) contract that selected based on lowest bid price offered. More than $42 \%$ of the contracts facing instability due to shipping delays. Often there is a delay from the supplier in sending spare parts materials beyond the time agreed upon with the company can hamper the production process. Therefore, it is necessary to evaluate the supplier. The procurement department at the company provides an on-time delivery performance for 67 existing contracts. The following 
The $6^{\text {th }}$ International Seminar on Science and Technology (ISST) 2020

July $25^{\text {th }} 2020$, Institut Teknologi Sepuluh Nopember, Surabaya, Indonesia

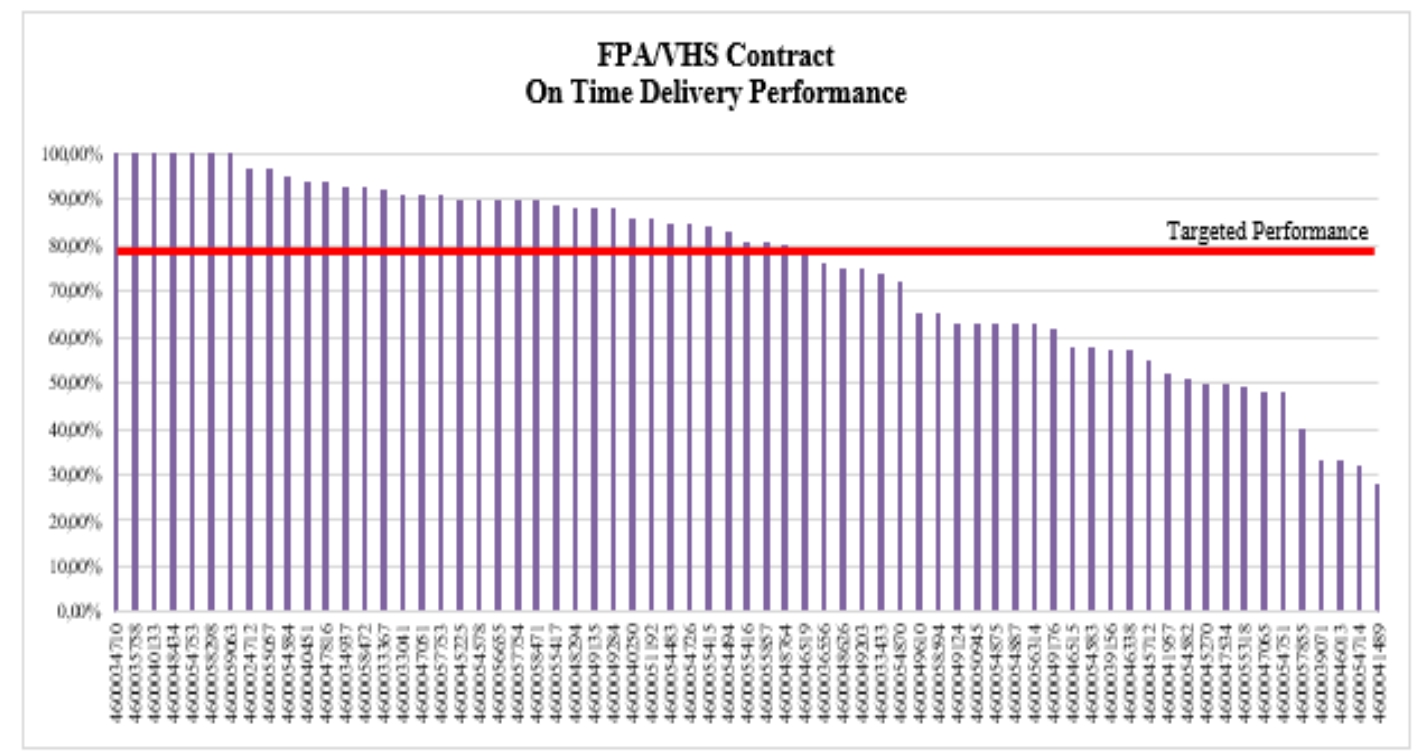

Figure 1. Existing supplier on-time delivery performance under FPA/VHS contract.

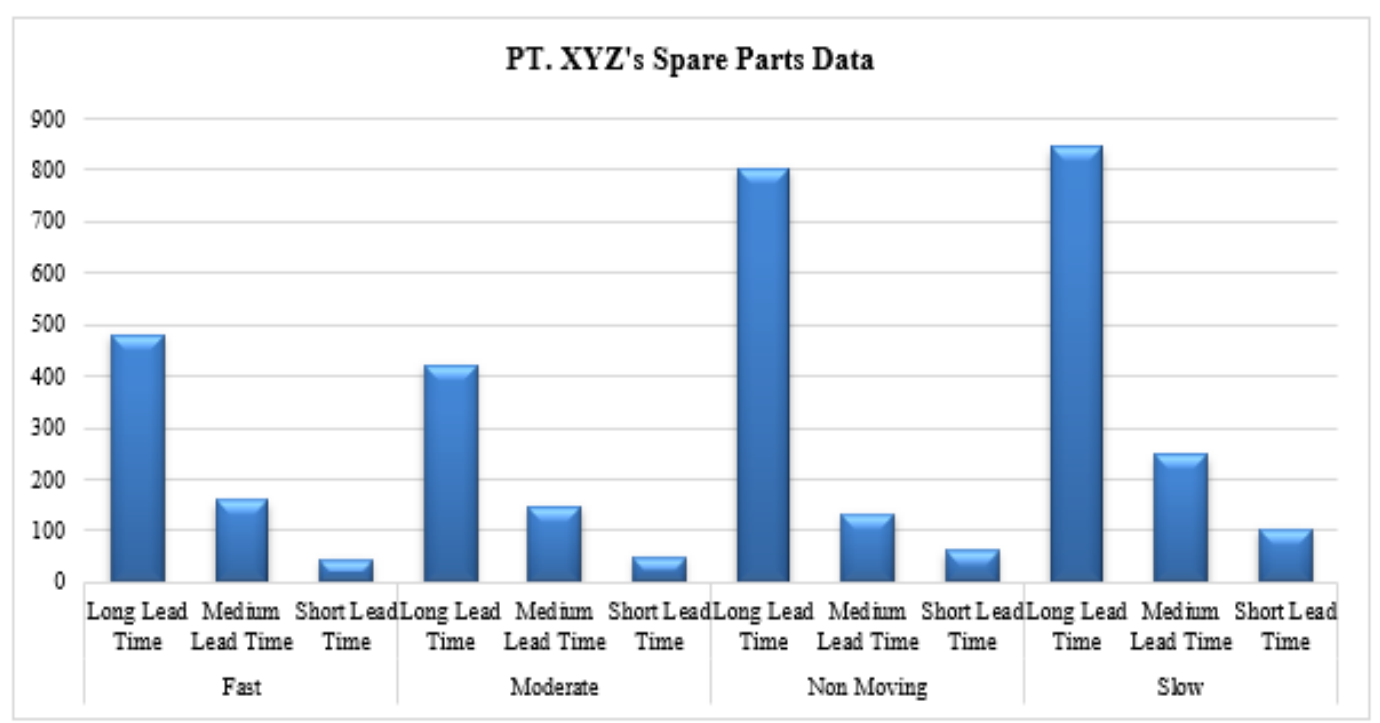

Figure 2. Spare parts material classifications of PT. XYZ based on the delivery lead time.

is data on-time delivery performance for spare parts materials under 67 contracts which can be seen in Figure 1. Spare parts material classifications of PT. XYZ based on the delivery lead time can be seen in Figure 2. In brief, the formulation of the problem in this study is as follows:

1. Identifying and analyzing the conditions and problems of supplier assessment criteria of PT. XYZ at the moment.

2. Propose supplier assessment criteria that will be used to select suppliers of spare parts.

3. Creating a model for evaluating spare parts material suppliers under the VMI contract using the Analytical Hierarchy Process method at PT. XYZ.

\section{AHP METHOD}

Analytic Hierarchy Process (AHP) is a process that helps decision makers to get the best solution by decomposing complex problems into simpler forms and then synthesizing various factors involved in the decision making problem [12]. AHP considers the qualitative and quantitative aspects of a decision [13] and reduce the complexity of a decision by making one-on-one comparisons of the various criteria chosen to then process and obtain results. This technique not only helps decision makers to obtain the best alternative solutions, but also provides a clear rational understanding of the choices made.

There are four basic principles of AHP that must be understood, namely [14]:

1. Decomposition, which is to break complex problems into simpler forms and arrange them into a hierarchical tree.

2. Comparative judgment, which is the process of assessing the relative importance of one criterion with other criteria at a certain level. This assessment affects the priority criteria that are the core of the AHP method. The results of this assessment are arranged in the form of a pairwise comparison matrix.

3. Synthesis of priority, which is the process of synthesis between local priorities in a hierarchical level to obtain global priorities from various criteria for a decision.

4. Local consistency, which is an assessment of the relative importance that is consistent between one criterion with 
The $6^{\text {th }}$ International Seminar on Science and Technology (ISST) 2020

July $25^{\text {th }} 2020$, Institut Teknologi Sepuluh Nopember, Surabaya, Indonesia

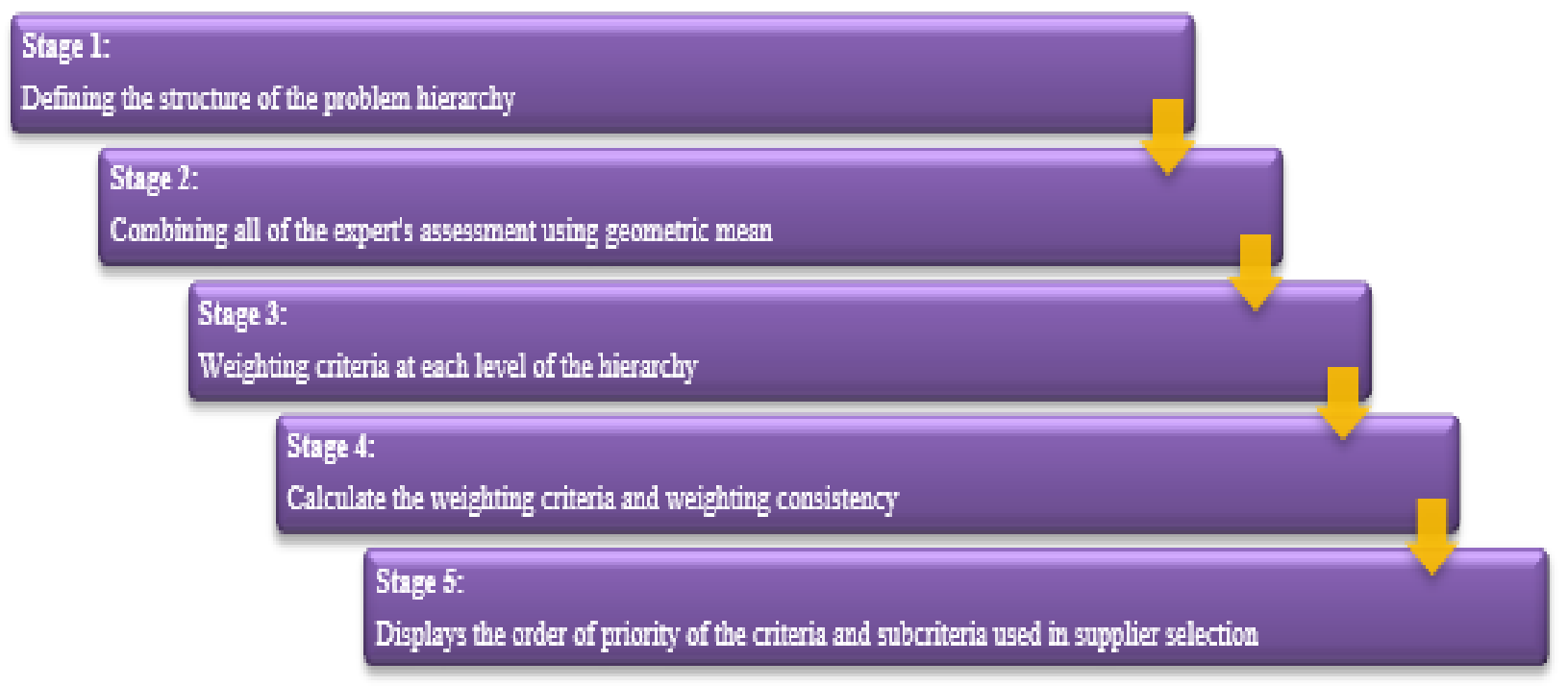

Figure 3. AHP method stages.

another. The stages carried out in the AHP method are generally illustrated in Figure 3.

Analytic Hierarchy Process (AHP) was developed by Saaty [15]. AHP is a widely used decision-making tool in various multi-criteria decision-making problems. It takes the pair-wise comparisons of different alternatives with respect to various criteria and provides a decision support tool for multi-criteria decision problems. In a general AHP model, the objective is in the first level, the criteria and sub-criteria are in the second and third levels respectively. Finally, the alternatives are found in the fourth level.

\section{A. Defining The Structure of The Problem Hierarchy}

Problems are decomposed into a hierarchical tree that shows the relationship between problems, criteria, and alternative solutions. The hierarchical tree is illustrated in Figure 4 [16].

The content analysis method is used to summarize the criteria and sub-criteria by the previous study, due to they were included in the influencing criteria and sub-criteria in Table 1 have to filter the most important criteria based on the scope of the study, based on experts assessment and brainstorming, in this case of the research study.

\section{B. Carrying Out Criteria and Subcriteria Weights at Each Level of The Hierarchy}

At this stage, all criteria at each level of the hierarchy are given an assessment of the relative importance of one criterion to another. Assessment uses the Saaty weighting standard on a scale from 1 to 9 and vice versa. Information about the scale can be seen in the following Table 2 [16].

Based on these criteria values a pairwise comparison $A$ matrix can be arranged as follows:

$$
A=\left[\begin{array}{ccccc}
a_{1,1} & a_{1,2} & a_{1,3} & \ldots & a_{1, j} \\
a_{2,1} & a_{2,2} & a_{2,3} & \ldots & a_{2, j} \\
a_{3,1} & a_{3,2} & a_{3,3} & \ldots & a_{3, j} \\
\vdots & \vdots & \vdots & \ldots & \vdots \\
a_{i, 1} & a_{i, 2} & a_{i, 3} & \ldots & a_{i, j}
\end{array}\right]
$$

$a_{i j}$, represents the matrix element $A$ in row $i$ column $j$.

\section{Calculate The Weighting Criteria and Weighting Consistency}

This stage calculates the priority weighting by finding the eigenvector value of matrix A through the following process.

\section{Displays The Order of Priority of The Criteria and} Subcriteria Used in Supplier Selection

1. Combine respondent's assessments of the relative importance of each criterion and subcriterion. Group assessments in AHP can be combined into one rating, namely through the geometric mean of respondent's assessments.

$$
G M=\sqrt[n]{\left(x_{1}\right)\left(x_{2}\right)\left(x_{3}\right) \ldots\left(x_{n}\right)}
$$

Where:

$$
\begin{array}{ll}
\mathrm{GM} & =\text { Geometric Mean } \\
\mathrm{x}_{1} & =\text { Expert } 1 \\
\mathrm{x}_{2} & =\text { Expert } 2 \\
\mathrm{x}_{3} & =\text { Expert } 3 \\
\mathrm{x}_{\mathrm{n}} & =\text { Expert } \mathrm{n} \\
\mathrm{n} & =\text { Number of Experts }
\end{array}
$$

2. Squared matrix $A$. The value of the element matrix $A^{2}$ is determined using the following formula:

$$
a i, j 2=\sum_{k=1}^{n} a_{i, k} \cdot a_{k, j}
$$

$a_{i, k}$, represents the matrix element $A$ in the row $i$ to column $k$ and $a_{k, j}$, represents the element of matrix $A$ in the column $j$ to row $k$.

3. Sum the elements for each row of matrix $A^{2}$ to get a matrix B using the following formula:

$$
b i=\sum_{j=1}^{n} a_{i, j}=a_{i, j}+a i, 2+a i, 3+\ldots+a i, j
$$

$b_{\text {i }}$ represents the matrix element $\mathrm{B}$ in line $i$. Matrix $\mathrm{B}$ is arranged using element $b_{\mathrm{i}}$ as follows:

$$
B=\left[\begin{array}{c}
b_{1} \\
b_{2} \\
b_{3} \\
\vdots \\
b_{i}
\end{array}\right]
$$


The $6^{\text {th }}$ International Seminar on Science and Technology (ISST) 2020

July $25^{\text {th }} 2020$, Institut Teknologi Sepuluh Nopember, Surabaya, Indonesia

Table 1.

List of Important Criteria of the Study

\begin{tabular}{|c|c|c|}
\hline Main Criteria & Sub criteria & Description \\
\hline \multirow{5}{*}{ Quality } & Product quality & The products offered are quality without defects and have certifications for certain products. \\
\hline & Packaging quality & Products are well packaged and packaging is suitable for transportation and storage. \\
\hline & Reliability & Reliability of the products offered. \\
\hline & $\begin{array}{l}\text { Percentage of products } \\
\text { rejected }\end{array}$ & $\begin{array}{l}\text { The percentage of products rejected both in quality and quantity is the intensity of the product } \\
\text { rejected compared to the number of orders (PO) given to the supplier. }\end{array}$ \\
\hline & $\begin{array}{l}\text { Compliance with } \\
\text { specifications }\end{array}$ & Match between material specifications requested by the customer and those offered by the supplier. \\
\hline \multirow{5}{*}{ Price } & Competitive price & The total price offered by the supplier \\
\hline & Payment terms & Payment term offered by the supplier. \\
\hline & Price validity & How long supplier can hold the same price \\
\hline & Quantity Price Discount & The ability of suppliers to provide discounts for relatively large quantities of material purchases. \\
\hline & On time delivery & $\begin{array}{l}\text { Delivery is done according to the date indicated on the Purchase Order (PO) with the appropriate } \\
\text { lead time. }\end{array}$ \\
\hline \multirow{6}{*}{ Delivery } & Appropriate amount sent & $\begin{array}{l}\text { On time delivery of material quantities in accordance with the quantities listed on the Purchase } \\
\text { Order (PO) }\end{array}$ \\
\hline & $\begin{array}{l}\text { Complete shipping } \\
\text { documents }\end{array}$ & Material delivery documents must be accurate and complete. \\
\hline & Delivery capacity & The ability of the supplier at the time of delivery, the capacity of the conveyance. \\
\hline & Delivery time flexibility & The ability of suppliers to meet changes in delivery time, speed up delivery or delay delivery. \\
\hline & Short delivery lead time & The time needed for the supplier to supply the material. \\
\hline & Delivery Terms & Delivery terms offered by the suppliers \\
\hline \multirow{4}{*}{ Service } & Response flexibility & $\begin{array}{l}\text { The ability of suppliers to respond to changes based on demand, structural prices, frequency of } \\
\text { orders and changes in customer needs and is needed with better choices. }\end{array}$ \\
\hline & Warranty & $\begin{array}{l}\text { Insurance for the product and the length of the warranty period for products supplied when it is } \\
\text { defective or expires. }\end{array}$ \\
\hline & Technical support & Engineering and engineering support is easily provided during the product development stage. \\
\hline & $\begin{array}{l}\text { Speed of response to } \\
\text { claims }\end{array}$ & The time needed to respond to claims and make reimbursements. \\
\hline \multirow{7}{*}{$\begin{array}{l}\text { Supplier's } \\
\text { Background }\end{array}$} & Financial stability & An important factor that shows the company's position and performance in the market. \\
\hline & Geographical location & $\begin{array}{l}\text { Local suppliers can be trusted more than those located far from buyers, because the distance is } \\
\text { closer and the product is supplied by local suppliers so that it can be shipped faster and cheaper. }\end{array}$ \\
\hline & Supplier performance & Describe how the previous supplier performed \\
\hline & Professionalism & Professionalism \\
\hline & Distributor support letter & Described how the previous supplier performed \\
\hline & Product diversity & Many types of products that can be supplied by suppliers. \\
\hline & $\begin{array}{l}\text { Experience managing } \\
\text { VMI }\end{array}$ & Do suppliers have experience in managing cooperation contracts with the previous VMI system. \\
\hline \multirow{3}{*}{$\begin{array}{l}\text { Information } \\
\text { Technology }\end{array}$} & Innovation capacity & $\begin{array}{l}\text { Suppliers have technical knowledge and innovative product designs to improve updated products } \\
\text { and develop products. }\end{array}$ \\
\hline & $\begin{array}{l}\text { Information system } \\
\text { capacity }\end{array}$ & $\begin{array}{l}\text { Suppliers have technical knowledge and innovative product designs to improve updated products } \\
\text { and develop products. }\end{array}$ \\
\hline & $\begin{array}{l}\text { Information sharing } \\
\text { practice }\end{array}$ & $\begin{array}{l}\text { Suppliers have a management information system with good capacity, to manage the use of IT } \\
\text { infrastructure, and performance information between suppliers and customers and each supplier } \\
\text { shares data using better tools such as Electronic Data Interchange (EDI). }\end{array}$ \\
\hline
\end{tabular}

Add all the elements of matrix B using the following formula:

$$
\sum_{i=1}^{n} b_{i}=b_{1}+b_{2}+b_{3}+\ldots+b_{i}
$$

4. From the B matrix obtained in step 2 above, the normalization of the $\mathrm{B}$ matrix is then carried out to obtain the eigenvector value of the $\mathrm{B}$ matrix. The eigenvector values of matrix $B$ are described in the form of matrix $E$ as follows:

$$
E=\left[\begin{array}{c}
e_{1}=b_{1} / \sum_{i=1}^{n} b_{i} \\
e_{2}=b_{2} / \sum_{i=1}^{n} b_{i} \\
\cdots \\
e_{i}=b_{i} / \sum_{i=1}^{n} b_{i}
\end{array}\right]
$$

$e_{1}$ represents the element matrix E line $\mathrm{i}$.

5. The three processes above are carried out repeatedly and at the end of each iteration the difference between the $\mathrm{E}$ matrix value of the Eigenvector matrix is obtained by the previous eigenvector matrix $E$ value until a number close to zero is obtained. The E matrix obtained in the last step shows the priority criteria indicated by the coefficient of the eigenvector value.

\section{E. AHP Consistency}

Assessments between one criterion and another cannot be entirely consistent. This inconsistency can be caused by errors in entering judgments into the system, lack of information, lack of concentration, the real world that is not always consistent, or the hierarchical structure model that is less appropriate. The AHP method allows inconsistencies in the evaluation of criteria, but the inconsistencies in the assessment must not exceed the value of the consistency ratio of $10 \%$. This consistency ratio can be obtained by the following steps $[17,18,12]$ :

1. Calculate the $\lambda_{\max }$ of each order matrix by adding the product of the total weight of all criteria in each column of the matrix with the main eigenvector value of the matrix.

2. Calculate the consistency index value for each n-order matrix using the formula: 


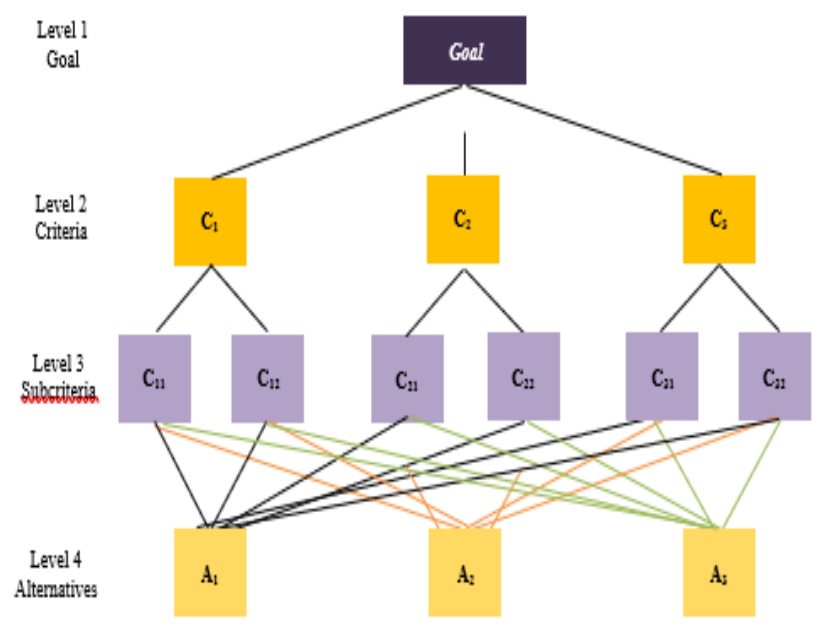

Figure 4. Hierarchical structure model.

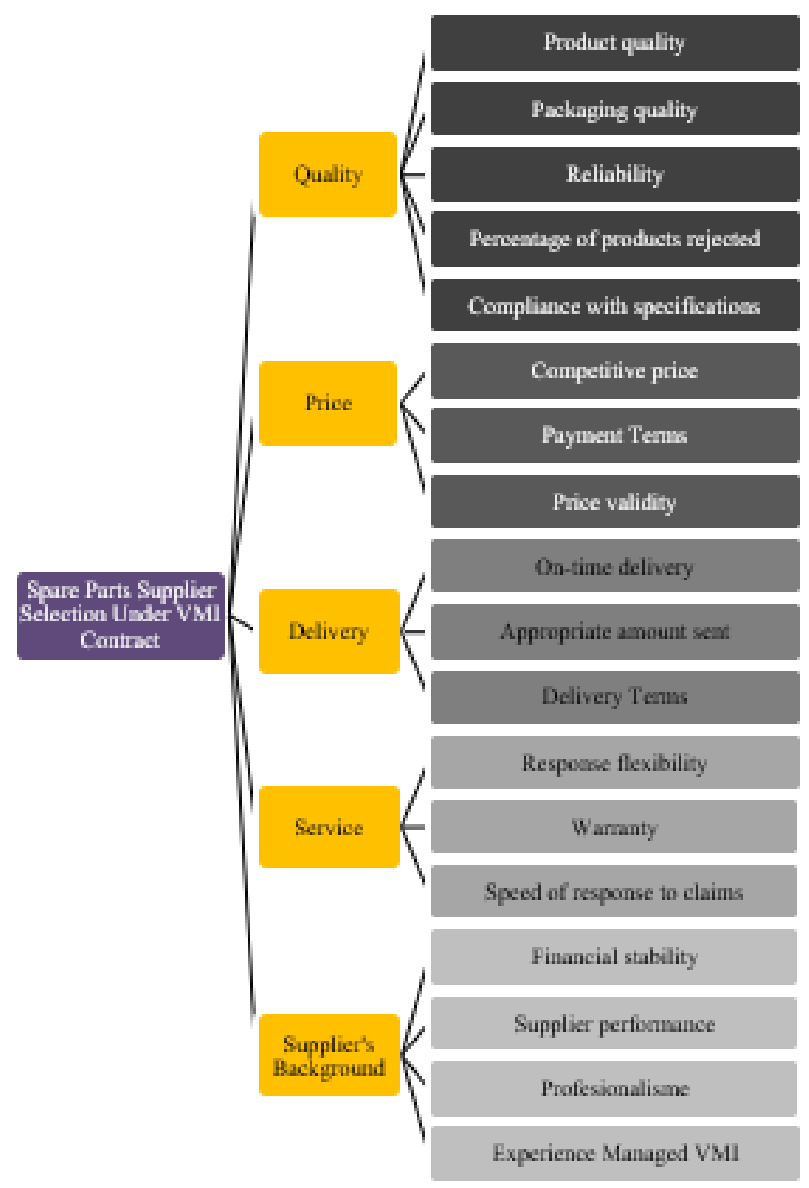

Figure 5. The model of the hierarchy of this research study.

$$
C I=\frac{\lambda_{\max }-n}{n-1}
$$

Where:

$\mathrm{CI}=$ consistency index

$\mathrm{n}=$ order of the matrix

$\lambda_{\max }=$ the largest eigenvector value of the order matrix $n$.

3. The consistency ratio can be calculated using the formula:

$$
C R=\frac{C I}{R I}
$$

Where:

$\mathrm{CR}=$ consistency ratio

$\mathrm{RI}=$ random index for each order matrix $\mathrm{n}$.
Table 2 .

Assessment of The Relative Importance of Criteria Using the Saaty

\begin{tabular}{cc} 
& Scale \\
\hline \hline Scale & Definition \\
\hline 1 & Equally important \\
3 & Moderate important \\
5 & Strongly important \\
7 & Very strongly important \\
9 & Extremely Important \\
$2,4,6,8$ & Intermediate value between adjacent scales \\
\hline \hline
\end{tabular}

Table 3 shows the random index values for each order matrix 1 through 10 .

4. This stage prioritizes the criteria and sub-criteria available. The largest number of values is the best choice.

\section{RESULT}

\section{A. The Influencing Criteria and Subcriteria In This Study Case}

The brainstorming and expert's voice from PT. XYZ, resulting 5 main criteria and 18 subcriteria in this case of the research study.

\section{B. Hierarchical structure model}

The hierarchical structure model of the AHP hierarchical framework model shown in Figure 5, which is the first level: The Goal, the seconds level: 5 the main criteria, and the thirds level: 18 Subcriteria follow.

\section{Determining Weights of Criteria and Subcriteria}

In order to determine the criteria for the supplier selection process, a Likert types scales questionnaires follow current scale (1-9) then the score can be evaluated by AHP methods for finding the highest priority of criteria in this study [19]. In order to judge the score of each criterion by 5 experts who worked at PT. XYZ, with the procurement managers and material management managers. According to their preferences, the averaged pairwise comparison of the criteria is represented by the following Table 4.

From the pairwise comparisons above we can calculate the priority of each criterion based on its contribution to the goal. Namely by dividing each element from the matrix by the total number of columns, then averaging the elements in each row so we get the weight of each criterion. These criteria weights are then used to assess the priority of each criterion. The priority of each criterion is shown in Table 5.

From the weight of the criteria above it can be seen that quality is the criterion with the highest priority followed by price, delivery, service and supplier background.

\section{Calculate Consistency Ratio}

Table 6, Table 7, and Table 8 has illustrated the result of the final weight of each criterion which the "Competitive price" factor is the highest score. When we look at the result from the customer perspective, we can see that the most priority weight are "Quality" has released value (0.306) and following by "Price" with the priority of (0.259), "Delivery" (0.213), "Service" (0.126) and lowest values of (0.096) is Supplier's background" factor in this study case, where it is consistency ratio as CR value within 0.013 is less than 0.1 , is an acceptable solution from AHP formula rule in order to 
The $6^{\text {th }}$ International Seminar on Science and Technology (ISST) 2020

July $25^{\text {th }} 2020$, Institut Teknologi Sepuluh Nopember, Surabaya, Indonesia

Table 3 .

Value for Random of Consistency Index (RI)

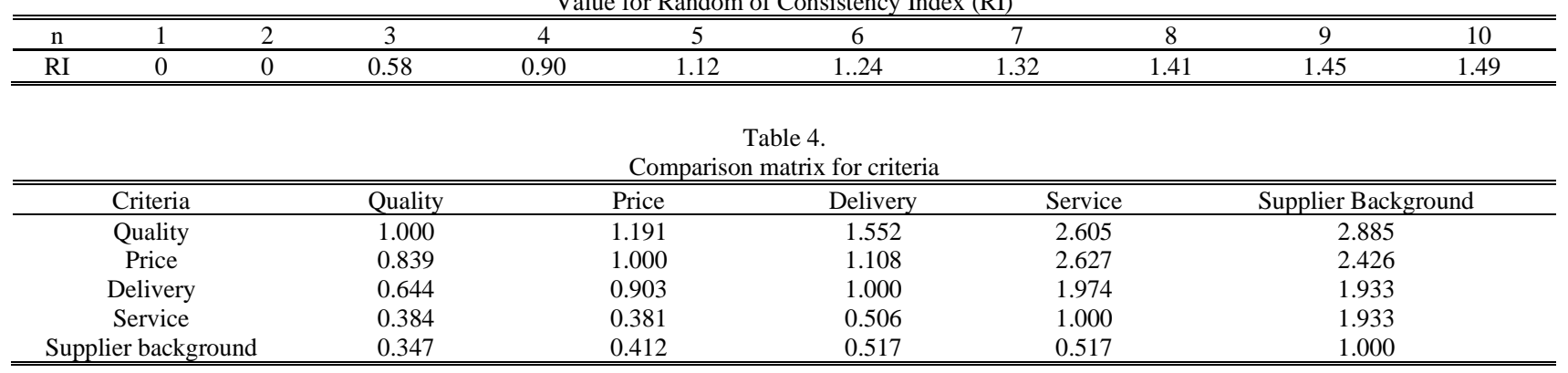

Table 5 .

Priority criteria

\begin{tabular}{ccccccc}
\hline \hline Criteria & Quality & Price & Delivery & Service & Supplier Background & Weight \\
\hline Quality & 0.311 & 0.306 & 0.331 & 0.299 & 0.284 & 0.306 \\
Price & 0.261 & 0.257 & 0.236 & 0.301 & 0.238 & 0.259 \\
Delivery & 0.200 & 0.232 & 0.214 & 0.226 & 0.190 & 0.213 \\
Service & 0.119 & 0.098 & 0.108 & 0.115 & 0.098 & 0.126 \\
Supplier background & 0.108 & 0.106 & 0.110 & 0.059 & 0.098 & 0.096 \\
\hline \hline
\end{tabular}

Table 6.

The result of each weight of criteria dan sub criteria

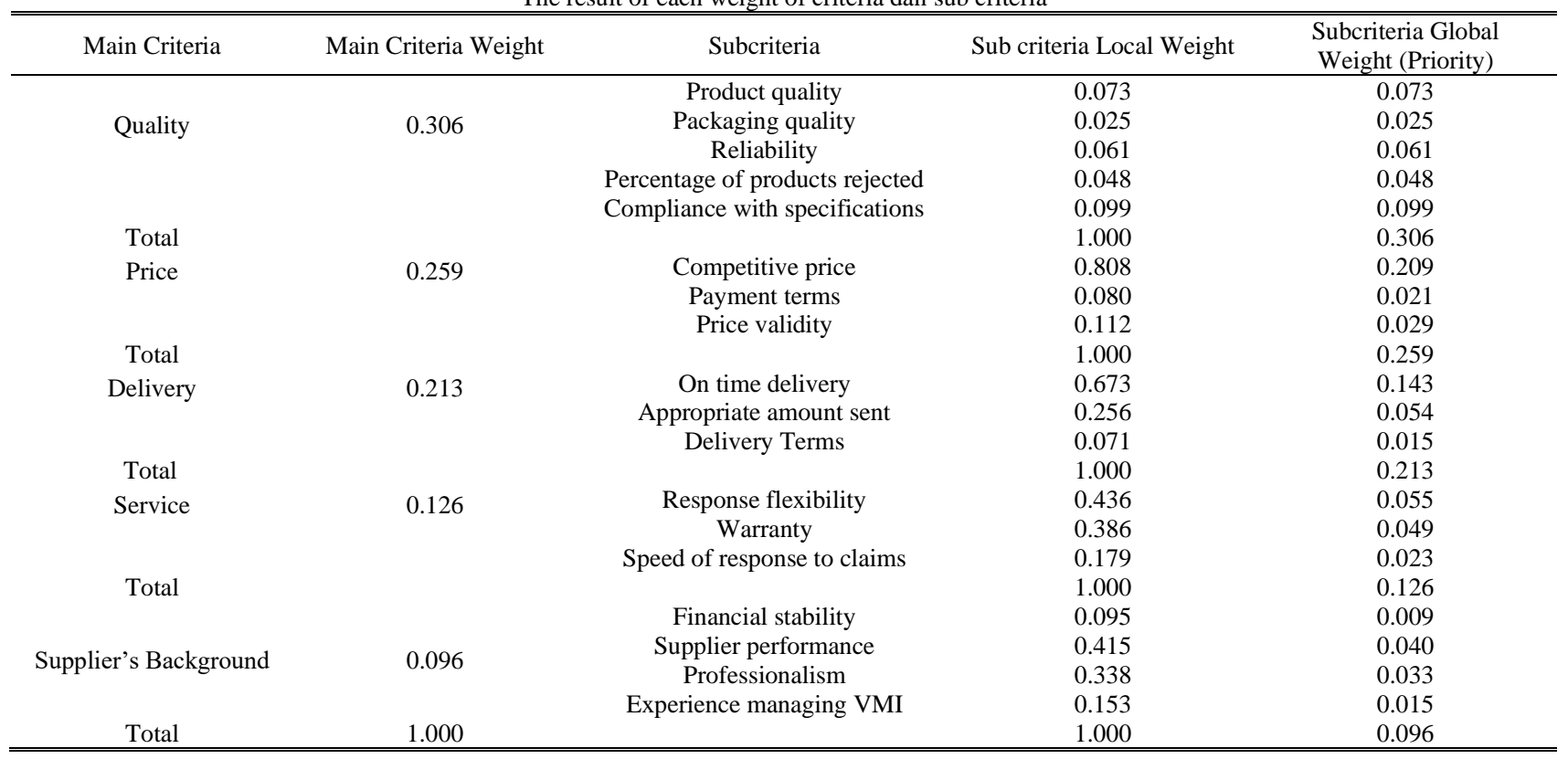

Table 7.

Calculation of CI and CR - Criteria

\begin{tabular}{cccccccc}
\hline \hline Criteria & Quality & Price & Delivery & Service & Supplier Background & Total & Total/Weight \\
\hline Quality & 0.306 & 0.308 & 0.330 & 0.328 & 0.278 & 1.551 & 5.064 \\
Price & 0.257 & 0.259 & 0.235 & 0.331 & 0.234 & 1.316 & 5.084 \\
Delivery & 0.197 & 0.234 & 0.213 & 0.249 & 0.186 & 1.079 & 5.076 \\
Service & 0.118 & 0.099 & 0.108 & 0.126 & 0.186 & 0.636 & 5.047 \\
Supplier background & 0.106 & 0.107 & 0.110 & 0.065 & 0.096 & 0.484 & 5.025 \\
& & & & & & & \\
& & & & & & \\
\hline \hline
\end{tabular}

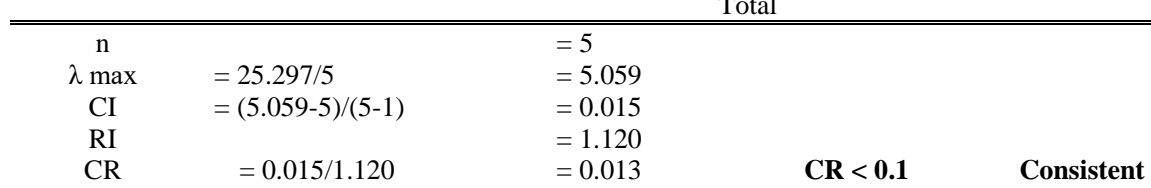

continue for making a decision on the alternatives in last with the suggestion of influencing criteria for spare parts supplier selection in the mining company case of VMI adoption after evaluating of this study. Another talking about the diagram in Figure 6 has shown the result of the priority of each subcriteria weight are 18 subcriteria from 5 main criteria of this study which the following this value in Table 6 .

Anyway, in Figure 2 is found that the three top values of subcriteria which they mostly are influencing criteria on supplier selection in mining company for the adoption of 
The $6^{\text {th }}$ International Seminar on Science and Technology (ISST) 2020

July $25^{\text {th }}$ 2020, Institut Teknologi Sepuluh Nopember, Surabaya, Indonesia

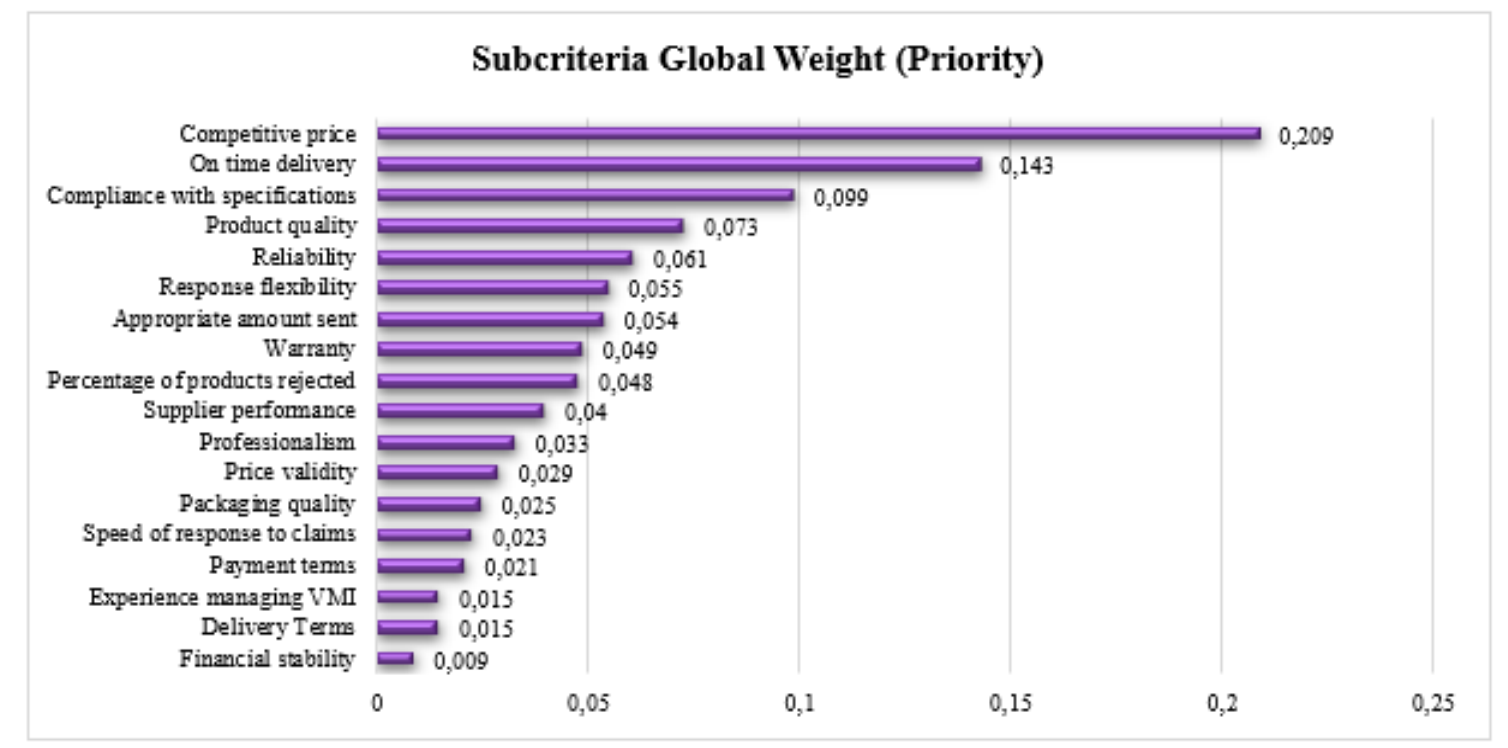

Figure 6. Weight of subcriteria priority of this study.

Table 8 .

Calculation Result of CR For Every Expert

\begin{tabular}{|c|c|c|c|c|c|c|c|c|c|c|c|}
\hline Main Criteria & $E_{1}$ & $\mathrm{E}_{2}$ & $\mathrm{E}_{3}$ & $\mathrm{E}_{4}$ & $\mathrm{E}_{5}$ & Subcriteria & $E_{1}$ & $\mathrm{E}_{2}$ & $E_{3}$ & $\mathrm{E}_{4}$ & $E_{5}$ \\
\hline Quality & & & & & & $\begin{array}{l}\text { Product quality } \\
\text { Packaging quality } \\
\text { Reliability } \\
\text { Percentage of products } \\
\text { rejected } \\
\text { Compliance with } \\
\text { specifications }\end{array}$ & 0.026 & 0.097 & 0.038 & 0.033 & 0.045 \\
\hline Price & 0.031 & 0.083 & 0.048 & 0.051 & 0.055 & $\begin{array}{l}\text { Competitive price } \\
\text { Payment terms } \\
\text { Price validity } \\
\text { On time delivery }\end{array}$ & 0.046 & 0.025 & 0.057 & 0.033 & 0.071 \\
\hline Delivery & & & & & & $\begin{array}{l}\text { Appropriate amount sent } \\
\text { Delivery Terms } \\
\text { Response flexibility }\end{array}$ & 0.016 & 0.025 & 0.046 & 0.033 & 0.057 \\
\hline Service & & & & & & $\begin{array}{l}\text { Warranty } \\
\text { Speed of response to claims }\end{array}$ & 0.033 & 0.025 & 0.057 & 0.025 & 0.011 \\
\hline $\begin{array}{l}\text { Supplier's } \\
\text { Background }\end{array}$ & & & & & & $\begin{array}{l}\text { Supplier performance } \\
\text { Professionalism } \\
\text { Experience managing VMI }\end{array}$ & 0.054 & 0.097 & 0.080 & 0.047 & 0.012 \\
\hline
\end{tabular}

VMI system such as "Competitive price, On-time delivery, and Compliance with specifications", are the priority weight of $0.209,0.143$ and 0.099 respectively, which the products have referred to spare parts product for both procurement and material management in terms of increasing service level of the warehouse.

\section{CONCLUSION}

This study focuses on identifying influencing criteria in the mining company as the company which wants to encourage their suppliers to adopt vendor managed inventory (VMI) tool as advance technology for quick response and feedback as possible. The spare parts may be useful for helping maintenance on time and improve warehouse service satisfaction.

Depending on the results of this study, the most important influencing criteria is a quality factor in supplier selection. About the most top three influencing sub-factors are the "Competitive price, On-time delivery, and Compliance with the specification" which they can be recommended to the material management manager and the procurement units have to develop the quality of assessment protocol of spare part products and supplier could be the best information sharing with good quality and long term of cooperation, innovative products, and reliability of each data by encouraging between the company and their suppliers through to the adoption of VMI systems within EDI tool or database in the computer system.

The AHP tool is the powerful and useful tool for making decision process into user in right design which it can work the better decision on choosing the vendors and suppliers to the best practices between suppliers and the company that it required the qualified set of experts who are specialized in solving the problem with maintenance sector.

The advantages of this research studied criteria, it could be to suggest to the enterprise for choosing the qualified supplier who supplies the spare part products for the maintenance in order to evaluate the quality of products, a good price, ontime delivery, and the service with a potential supplier for a mining company. 
The $6^{\text {th }}$ International Seminar on Science and Technology (ISST) 2020

July $25^{\text {th }} 2020$, Institut Teknologi Sepuluh Nopember, Surabaya, Indonesia

The future work is the researchers can apply the effective criteria of this study due to making a better decision on suppliers who provide spare parts products for mining companies within a good negotiation and quality of information by sharing useful information between company and supplier. The key improvement recommendation will reduce customers' dissatisfaction, costs, safety stocking level, and improve better communication, better price, and reliable of good quality of products. The suppliers should be the best practice on product quality, good information, and quality of information, reliability all data sharing and quick response and feedback, and the last one is the price is a standard price on the market price in the present and future.

\section{REFERENCES}

[1] Krajewsld, L.J., and Ritzman, L.P., Operations Management Strategy and Analysis. Addison-Wesley Publishing Co., London, UK, 1996.

[2] Önüt, S., Kara, S.S., and Işık, E, "Long Term Supplier Selection Using a Combined Fuzzy MCDM Approach: A Case Study for a Telecommunication Company", Expert Systems with Applications Vol. 36(2), 3887-3895, 2009.

[3] Liao, C.N., and Kao, H.P., "An Integrated Fuzzy TOPSIS and MCGP Approach to Supplier Selection in Supply Chain Management", Expert Systems with Application Vol.38(9), 2011, 10803-10811,.

[4] Kilic, H.S., "An integrated approach for supplier selection in multiitem/multi-supplier environment", Applied Mathematical Modelling, Vol. 37 (14-15), 2013, 7752-7763.

[5] Dickson, G.W., "An Analysis of Vendor Selection Systems and Decision". Journal of Purchasing Vol.2(1), 1966, 5-17.

[6] Jolai, F., Yazdian, S.A., Shahanaghi, K., and Khojasteh, M.A., "Integrating Fuzzy TOPSIS and Multi-Period Goal Programming for Purchasing Multiple Products From Multiple Suppliers", Journal of Purchasing \& Supply Management, Vol.17(1), 2011, 42-53.

[7] Weber, C.A., Current J.R. and Benton, W.C. "Vendor Selection Criteria and Methods", European Journal of Operational Research Vol.50(1), 1991, 2-18.
[8] De Boer, L., Labro, E. and Morlacchi, P., "A Review of Methods Supporting Suppliers Selection", European Journal of Purchasing and Supply Management Vol. 7(2), 2001, 75-89.

[9] Boran, F.E., Genç, S., Kurt, M., and Akay, D., “A Multi-Criteria Intuitionistic Fuzzy Group Decision Making for Supplier Selection with TOPSIS Method", Expert Systems with Applications Vol. 36 (8), 2009, 11363-11368.

[10] Waller, M., Johnson, M.E., and Davis, T. Vendor-managed inventory in the retail supply chain. Journal of business logistics. 1999;20:183-204.

[11] Koul, S. and Verma, R. "Dynamic Vendor selection: a fuzzy AHP approach". International Journal of Manufacturing Technology Management. Vol. 22, No.8, 2009,

[12] Forman, Ernest H. "Decision by Objectives". Department of Decision Science, School of Business, The George Washington University, 2006.

[13] Saaty, Thomas L. and Michael P. Niemera., "A Framework for Making a Better Decision: How to Make More Effective Site Selection, Store Closing, and Other Real Estate Decisions." Research Review, Vol.13 (1), 2006, 4.

[14] Latifah, S., "Prinsip-prinsip Dasar Analytic Hierarchy Process". Jurusan Kehutanan, Fakultas Pertanian, Universitas Sumatera Utara, 2005.

[15] Saaty, T.L., "The Analytic Hierarchy Process", McGraw-Hill, New York, USA, 1980.

[16] Haas, Rainer and Meixner, Oliver, "An illustrated Guide to the Analytic Hierarchy Process". Institute of Marketing \& Innovation, University of Natural Resources and Applied Life Sciences, Vienna, 2005.

[17] Atthirawong, W., and MacCarthy, B. "An Application of the Analytic Hierarchy Process to International Location Decision Making". Operations Management Group, School of Mechanical, Materials, Manufacturing Engineering and Management, University of Nottingham, NG7 2RD, 2002.

[18] Teknomo, K., Siswanto, H., and Yudhanto, S.A., "Penggunaan Metode Analytic Hierarchy Process Dalam Menganalisa Faktorfaktor yang Mempengaruhi Pemilihan Moda ke Kampus”. Jurusan Teknik Sipil, Fakultas Teknik, Universitas Kristen Petra, 1999.

[19] Saaty, T. L., "Theory and Applications of The Analytic Network Process: Decision Making With Benefits, Opportunities, Costs, and Risks". RWS Publications, 2005. 